\title{
1.3.3. Zróżnicowane grupy uczniów - jakie problemy?
}

DOI: 10.47050/65591838.62-69

Grzegorz Szumski

Współczesne uwarunkowania rozwoju społeczeństw i systemów edukacyjnych nie pozostawiają nam możliwości większego wpływu na różnicowanie się klas szkolnych i grup wychowawczych. Proces ten po prostu następuje, a teoria i praktyka pedagogiczna muszą poszukiwać optymalnych sposobów reagowania na zmieniającą się rzeczywistość. Główną odpowiedzią na te wyzwania jest koncepcja edukacji włączającej, której poświęcona jest ta książka. Nie należy oczywiście lekceważyć faktu, że duża heterogeniczność klas szkolnych i grup wychowawczych stanowi poważne wyzwanie dla nauczycieli i wychowawców. Niniejszy podrozdział poświęcony jest analizie właśnie tych wyzwań i możliwych sposobów radzenia sobie z nimi. Rozpoczniemy od prezentacji rozwiązań organizacyjno-metodycznych lekcji, którymi potencjalnie dysponują nauczyciele i które mogą służyć dostosowywaniu procesu nauczania do zróżnicowanych potrzeb uczniów. Następnie omówimy specyficzne cechy uczniów z lekką niepełnosprawnością intelektualną, wskazując, które propozycje metodyczne mogą być dla nich odpowiednie. Objętość opracowania nie pozwala na taką analizę w odniesieniu do wszystkich rodzajów niepełnosprawności. Z tego powodu wybraliśmy tę, która jest najczęstszą przyczyną orzekania potrzeby kształcenia specjalnego w Polsce. Omawiany przykład ma czytelnikom uświadomić złożoność problemów dydaktycznych, z którymi muszą zmagać się nauczyciele.

Najważniejszym ich zadaniem w edukacji włączającej jest takie przygotowywanie i prowadzenie zajęć oraz lekcji, aby mogli z nich efektywnie korzystać uczniowie o zróżnicowanych potrzebach. W pewnym 
uproszczeniu można powiedzieć, że dwa typy sytuacji na takich lekcjach są niepożądane, a zatem zadaniem nauczyciela jest ich eliminowanie (lub przynajmniej minimalizowanie). Pierwszy to taki, gdy zajęcia edukacyjne są niedostosowane do specyficznych cech niektórych uczniów. Są oni zatem obecni w klasie, ale ze względu na nieadekwatne dla nich treści, sposób ich przekazu lub zadania nie robią postępów. Sytuacja druga występuje wtedy, gdy w jednej sali lekcyjnej realizowane są w praktyce dwie różne ścieżki edukacyjne - osoby z orzeczeniem o potrzebie kształcenia specjalnego nauczane są stale czegoś innego, w inny sposób i przez innego pedagoga niż ich koledzy i koleżanki. Ta sytuacja jest oczywiście możliwa tylko wtedy, gdy w klasie pracuje równocześnie co najmniej dwóch nauczycieli.

Istnieją dwie kluczowe strategie, które można wykorzystywać w klasach włączających po to, aby eliminować wspomniane sytuacje niepożądane, a tym samym zwiększać adekwatność lekcji do zróżnicowanych potrzeb uczniów, zapewniając jednocześnie spójność prowadzonych zajęć edukacyjnych. Są to: uniwersalne projektowanie oraz indywidualizacja nauczania.

Uniwersalne projektowanie nauczania (universal design for learning, UDL) jest bardzo popularną strategią doskonalenia kształcenia, rozwijaną w świecie od około trzech dekad. Ponieważ wiele ważnych informacji na jej temat zostało zawartych w odrębnym rozdziale tej książki, tutaj ograniczymy się tylko do interesujących kwestii dla tego wywodu. Głównym celem projektowania uniwersalnego jest zwiększenie możliwości osiągania tych samych celów przez różnych użytkowników, a w edukacji - uczestników tego samego procesu. Zakłada się zatem, że uniwersalne rozwiązania są korzystne dla szerokiej grupy odbiorców, a jednocześnie nie są szkodliwe dla żadnego odbiorcy. Dobrze ilustrują to dwa przykłady zaczerpnięte z architektury, gdzie zrodził się ten pomysł. Szersze drzwi do domu są korzystne nie tylko dla osób jeżdżących na wózkach inwalidzkich, ale także dla pracowników prowadzących remont domu, osób otyłych, rodziców wprowadzających wózek dziecięcy czy ludzi nieuważnych, którzy w wąskim przejściu mogą zniszczyć swoje ubranie. Z rozwiązania tego korzystają także "zwykli" ludzie - po prostu jest im wygodniej dostać się do pomieszczenia. Napisy brajlowskie na przyciskach w windzie ułatwiają życie osobom niewidomym, a przez pozostałych użytkowników są po prostu ignorowane. W nauczaniu o wiele trudniej o tego typu rozwią- 
zania ze względu na specyfikę tego procesu (Edyburn 2010). Istnieją trzy komponenty procesu nauczania/uczenia się, które mogą stanowić bariery dla niektórych grup uczniów i którym potencjalnie może zaradzić UDL: percepcja materiału (treści i poleceń), planowanie zadań, a zwłaszcza ich wykonywania, oraz motywacja do uczenia się i wiara $w$ to, że uczeń zrealizuje zadania szkolne lub poczyni satysfakcjonujące postępy (Pisha, Coyne 2001).

Efektywne wykorzystanie UDL do zapobiegania wskazanym ograniczeniom zależy w znacznej mierze od wybieranych przez nauczycieli strategii nauczania. Niestety, UDL ma ograniczone zastosowanie w nauczaniu frontalnym, które sprawia największe problemy w klasach włączających, a jednocześnie często jest stosowane w polskich szkołach. W praktyce przy zastosowaniu tej strategii największa przestrzeń pozostaje dla wielomodalnego przekazu informacji bądź przekazu głównego, uzupełnianego informacją dodatkową, np. gdy nauczyciel mający zamiar omawiać jakiś temat wyjaśnia wcześniej kluczowe pojęcia lub wyświetla ich objaśnienia za pomocą rzutnika. Dużo szersze możliwości wykorzystania UDL daje praca indywidualna. Na przykład niezwykle efektywne są zaawansowane komputerowe programy edukacyjne, które dobierają uczącemu się kolejne zadania na podstawie oceny jego aktualnych umiejętności (Holmes, Gathercole, Dunning 2009). Dzieje się tak dlatego, że aplikacje tego rodzaju dostarczają uczniom zadania adekwatne do ich możliwości, a zatem tworzą sytuacje ułatwiające rzeczywiste uczenie się, budują "rusztowania" potrzebne do zdobywania bardziej zawansowanych umiejętności i zwiększają wiarę uczniów w ich możliwości, umożliwiając im odnoszenie sukcesów. Chociaż przywołany przykład ma małe znaczenie praktyczne z powodu ograniczonej podaży tego typu programów, to dobrze obrazuje dwie ważne kwestie. Po pierwsze, choć wspomniany program jest zaprojektowany zgodnie z zasadami UDL (zwiększa efektywność nabywania tej samej kompetencji, osiągania tego samego celu) przez wszystkich użytkowników, to mechanizm jego działania bazuje na zasadzie indywidualizacji. W praktyce istnieje bardzo nieostra granica między UDL a indywidualizacją nauczania. Po drugie, program działa dzięki wykorzystaniu zaawansowanych technologii informacyjnych. Istnieje oczywiście wiele materiałów metodycznych zaliczanych do UDL, które nie wymagają skomplikowanych rozwiązań technicznych (por. Rapp 2014), ale to jednak technologia w największym stopniu 
wpływa na zwiększanie uniwersalności nauczania (Edyburn 2010). Podsumowując, UDL jest z pewnością użyteczne dla edukacji włączającej, jednak nie rozwiązuje wszystkich problemów związanych z efektywnym nauczaniem grup heterogenicznych. Ponadto strategia ta nie jest intuicyjna ani tożsama z dobrymi praktykami dydaktycznymi. Potrzebne są zarówno materiały metodyczne niezbędne do jej stosowania, jak i specjalne szkolenia dla nauczycieli, które powinny być oferowane zarówno na etapie kształcenia, jak i doskonalenia zawodowego (Edyburn 2010).

Konstruktywną odpowiedzią na wiele specjalnych potrzeb edukacyjnych, których nie jest w stanie zaspokoić UDL, jest indywidualizacja nauczania. Warto zwrócić uwagę, że nie będzie ona możliwa, gdy zastosuje się nauczanie frontalne, czyli przekazywanie jednocześnie całej klasie tych samych treści (choć w tej sytuacji można wykorzystać UDL). Indywidualizacja polega na różnicowaniu oddziaływań kierowanych do poszczególnych uczniów w taki sposób, aby nauczanie było dostosowane do każdego z nich (Deunk, Smale-Jacobse, de Boer, Doolaard, Bosker 2018).

Każdy wymiar procesu nauczania/uczenia się może podlegać zróżnicowaniu, szczególnie cele i związany z nimi zakres treści, stopień trudności zadań i czas na ich wykonanie, a nie tylko sposoby nabywania tej samej wiedzy (Konarzewski 2011). James M. Kauffman od wielu lat upowszechnia pogląd, że duża intensywność indywidualizacji kształcenia jest konstytutywną cechą kształcenia specjalnego (por. Kauffman, Hung 2009). Nie kwestionuje on popularnego wśród zwolenników edukacji włączającej poglądu, że „to, co jest dobre dla uczniów z niepełnosprawnością, jest dobre dla pozostałych". Zatem umiejętne indywidualizowane lekcji, oparte na starannym rozpoznawaniu postępów poszczególnych uczniów, może przynosić korzyści wszystkim, także tym z potrzebą kształcenia specjalnego. Jest to zatem bardzo ważna strategia nauczania w klasach włączających. Trzeba jednak zaakceptować fakt, że niektóre osoby potrzebują tak intensywnej indywidualizacji nauczania, że nie można im jej zapewnić w klasie z jednym nauczycielem, który ponadto nie posiada gruntownego wykształcenia w zakresie pedagogiki specjalnej (Kauffman, Mock, Ward, Badar 2016). Sytuacja ta dotyczy uczniów, którzy ze względu na obecny poziom rozwoju muszą nabywać kompetencje kluczowe, które ich koledzy opanowali wcześniej (np. nauka czytania od podstaw w sytuacji, gdy reszta klasy już dobrze czyta i wykorzystuje tę umiejętność do zdobywania nowej wiedzy), 
potrzebują bardzo częstych informacji zwrotnych ukierunkowujących ich aktywność (których nie da się zapewnić przez dokładniejszą strukturalizację materiałów dydaktycznych) oraz bardzo częstych objaśnień materiału. W takich sytuacjach trudno mówić o pełnym, wspólnym uczestnictwie w lekcji nawet wtedy, gdy wszyscy uczniowie przebywają w jednym pomieszczeniu. Odpowiedni dla takiego zespołu sposób pracy zwykło się nazywać nauczaniem bezpośrednim. Polega on na tym, że nauczyciele, pracując "twarzą w twarz" z pojedynczymi osobami lub niewielkimi grupami, tłumaczą materiał podzielony na małe części, rozdzielają zadania lub stawiają pytania. Pozwala to kontrolować proces przyswajania poszczególnych partii wiedzy i opanowania umiejętności składowych danej kompetencji, a także natychmiast korygować błędy uczniów, co oznacza, że nauczyciele bezpośrednio kierują procesem uczenia się (Hornby 2014). Uczniowie z poszczególnymi rodzajami specjalnych potrzeb edukacyjnych różnią się zapotrzebowaniem na tego typu kształcenie. Trzeba dodać, że wymagania takie występują nie tylko u osób z głębszymi niepełnosprawnościami poznawczymi i niepełnosprawnościami sprzężonymi, ale także u wielu uczniów z dysfunkcjami Iżejszymi, wymagającymi mniej intensywnego wsparcia.

Mówiąc o wyzwaniach stojących przed nauczycielami, którzy mają efektywnie zajmować się heterogenicznymi grupami uczniów, warto wskazać nie tylko na czynniki substancjalne, wynikające właśnie z różnorodności grupy, ale także na trudności z zapewnieniem stosownych zasobów. Zarówno UDL, jak i nowoczesna indywidualizacja nauczania nie są rozwiązaniami intuicyjnymi, które mogą być efektywnie wdrażane przez przeciętnie wykształconych pedagogów bez wcześniejszego specjalnego przygotowania. Oba wymienione podejścia zawierają ogólne zasady, ale są dzisiaj w istocie zbiorem zamkniętych pakietów metodycznych, które nauczyciele muszą poznać i do stosowania których muszą otrzymać odpowiednie pomoce. W odniesieniu do indywidualizacji dobrze obrazuje to systematyczny przegląd opracowany przez Krzysztofa Konarzewskiego (2011). Badania wskazują ponadto, że stosowanie UDL, a zapewne także zaawansowanej indywidualizacji, stanowi duże obciążenia dla nauczycieli - wymaga od nich zwiększenia wysiłku i nakładów pracy, a także intensywniejszej współpracy ze specjalistami niż rozwiązania tradycyjne (Katz 2014). Chociaż dostosowywanie działań edukacyjnych do potrzeb zróżnicowanych grup uczniów jest koniecznością, to nie powinno być traktowane jako panaceum na 
wszelkie problemy. Badania efektywności indywidualizacji nauczania wskazują, że pozytywne rezultaty o wiele łatwiej uzyskać dzięki całościowym programom, do wdrażania których nauczyciele są gruntownie przygotowywani, a niejednokrotnie także wspierani przez specjalistów (Deunk, Smale-Jacobse, de Boer, Doolaard, Bosker 2018). Nieumiejętne indywidualizowanie nauczania może prowadzić do nieuzasadnionego obniżania wymagań i utrwalania u uczniów nieefektywnych strategii uczenia się (Corno 2008).

Z kolei skuteczność strategii UDL, ze względu na dużo krótszą historię tego rozwiązania, jest o wiele słabiej udokumentowana naukowo. Zdecydowana większość dostępnych analiz w zakresie jakości procesu nauczania i motywacyjnych cech uczniów przynosi obiecujące wyniki. Wskazuje się zatem na to, że UDL poprawia relacje nauczyciela z uczniami, redukuje stres szkolny uczniów, zwiększa ich zaangażowanie w zdobywanie wiedzy i podnosi ich poczucie samoskuteczności (Capp 2017). Ponieważ czynniki te wiązane są z większą efektywnością kształcenia, można racjonalnie oczekiwać, że UDL prowadzi także do poprawienia osiągnięć szkolnych. Brakuje jednak dowodów naukowych, które bezpośrednio potwierdziłyby tę tezę. Co więcej, nie ma także takich, które dotyczą efektywności UDL w pracy z osobami z poszczególnymi rodzajami niepełnosprawności. Nawet wyniki badań prowadzonych w klasach włączających nie są analizowane odrębnie dla tych grup uczniów (Capp 2017), co stanowi znaczne ograniczenie. Z badań efektywności indywidualizacji wiemy bowiem, że poszczególne rozwiązania nie przynoszą uniwersalnych skutków. Na przykład ewaluacje jednego z najpopularniejszych programów indywidualizacji nauczania w klasach włączających - ALEM - szczegółowo omówionego przez Konarzewskiego (2011), wykazały, że prowadzi on do poprawienia osiągnięć szkolnych uczniów z niepełnosprawnością, ale nie ma analogicznego wpływu na osiągnięcia pozostałych osób w klasie (Fuchs, Fuchs 1998).

Najliczniejszą grupą z orzeczeniami o potrzebie kształcenia specjalnego w Polsce są uczniowie z lekką niepełnosprawnością intelektualną. Stosunkowo często trafiają oni do szkół ogólnodostępnych i szkół (klas) integracyjnych. Przy okazji omawiania tej grupy warto wspomnieć, że do szkół ogólnodostępnych uczęszczają także osoby z inteligencją niższą niż przeciętna (borderline intellectual functioning), które nie mają wprawdzie orzeczeń o potrzebie kształcenia specjalnego, ale ich funkcjonowanie w środowisku szkolnym bardzo często przypomina 
sytuację uczniów z lekką niepełnosprawnością intelektualną (Peltopuro, Ahonen, Kaartinen, Seppälä, Närhi 2014). Sposób funkcjonowania poznawczego tej grupy ma wpływ na organizację adekwatnego do ich potrzeb nauczania w klasach włączających. Uczniowie z lekką niepełnosprawnością intelektualną mają wyraźnie większe trudności w rozumieniu nowego materiału i instrukcji do zadań niż ich rówieśnicy o prawidłowym rozwoju. Trudności te spowodowane są zarówno niższą wydolnością uwagi, osłabioną sprawnością funkcji poznawczych (spostrzeganie, zapamiętywanie czy myślenie), jak i opóźnieniami w rozwoju języka, który jest głównym narzędziem przekazywania materiału i instrukcji w szkole (Chrzanowska 2015; Hornby 2014). Cechy te sprawiają, że wiele standardowo stosowanych przez nauczycieli objaśnień nowego materiału lub instrukcji do pracy samodzielnej uczniów (indywidualnej lub grupowej) może być niezrozumiałych dla tych z lekką niepełnosprawnością intelektualną lub inteligencją niższą niż przeciętna. Pewne możliwości przeciwdziałania temu problemowi dają techniki uniwersalnego projektowania nauczania (np. objaśnianie trudniejszych pojęć, uzupełnianie przekazu słownego materiałem wizualnym czy wcześniejsze dostarczanie materiałów wprowadzających do nowego zagadnienia), ale w wielu sytuacjach mogą być one niewystarczające. Kluczową strategią powinno być zastąpienie frontalnego podawania materiału wszystkim uczniom oraz pogadanek prowadzonych z całą klasą innymi sposobami przekazywania wiedzy. Forma pisemna daje dużo większe możliwości w zakresie adaptacji materiału i instrukcji, jednak i ona wymaga od nauczycieli znacznego wysiłku przy opracowaniu materiałów dydaktycznych lub adaptacji istniejących, oferowanych przez wydawców.

Inną cechą osób z lekką niepełnosprawnością intelektualną są ograniczenia w zakresie planowania czynności poznawczych, które w połączeniu z dużą niepewnością w uczeniu się i słabą koncentracją uwagi tworzą specyficzne uwarunkowania procesu aktywnego zdobywania wiedzy przez samodzielną naukę. Metodycy od lat słusznie zalecają dzielenie materiału na mniejsze partie (Hornby 2014; Rola 2011). Jednak szkoła musi także aktywnie rozwijać zdolność uczniów do rozwiązywania coraz bardziej złożonych problemów, a skuteczną drogą do osiągnięcia tego celu jest udzielanie częstej informacji zwrotnej $w$ trakcie pracy nad dłuższymi i wieloetapowymi zadaniami szkolnymi. Nauczyciel musi mieć zatem w trakcie lekcji czas na to, żeby wielokrot- 
nie podejść do ucznia, by zapewnić go o tym, że pracuje prawidłowo lub udzielić informacji ukierunkowujących jego dalszą aktywność (Kowalik 1989). Żeby to było możliwe, pedagodzy powinni tak organizować proces kształcenia, aby pozostali uczniowie byli na lekcji możliwie najbardziej samodzielni. Kluczowym sposobem zapewniania takich warunków jest nauczanie otwarte, przystępnie opisane w poradniku metodycznym Bernda Badegrubera (1997).

Podsumowując, należy powiedzieć, że nauczanie w grupach silnie zróżnicowanych jest dla nauczycieli dużym wyzwaniem. Efektywności tego procesu nie uda się uzyskać wyłącznie przez modyfikację frontalnego sposobu nauczania, często stosowanego w tradycyjnych klasach. Dostosowanie kształcenia do zróżnicowanych potrzeb uczniów wymaga stosowania elastycznych rozwiązań, w tym UDL i indywidualizacji. Jednak odpowiedzialne używanie tych strategii wymaga starannego przygotowania, odpowiednich zasobów metodycznych, a niejednokrotnie także wsparcia ze strony specjalistów. Należy ponadto pamiętać, że nauczyciel nie jest w stanie zaspokoić potrzeb edukacyjnych wszystkich uczniów z niepełnosprawnością. Nawet ci z tzw. lekkimi niepełnosprawnościami wymagają niejednokrotnie intensywnego, bezpośredniego nauczania niektórych umiejętności. Osobami przygotowanymi do takiej pracy są pedagodzy specjalni. 